\title{
The Changing of Image of Islam in Japan: The Role of Civil Society in Disseminating Informations about Islam
}

\author{
Irma Rachmi Yulita ${ }^{1}$ and Susy Ong ${ }^{2}$ \\ \{1irma_rachmi@yahoo.co.id, ${ }^{2}$ susy.ong66@gmail.com\} \\ ${ }^{1,2}$ School of Strategic and Global Studies, Universitas Indonesia, Indonesia
}

\begin{abstract}
This research focuses on the image of Islam in Japan and the efforts to eradicate Islam's negative image created by the Japan's mass media. In preparation for the coming 2020 Olympic Games, the government as well as the local organization nationwide is taking initiatives to create a friendlier social condition toward foreigners, including Muslim foreigners. I try to look into their efforts to disseminate knowledge and informations about Islam to the general public. I have conducted in-depth interviews with 6 Muslims residing in Kobe, Kyoto, and Tokyo, and compared their stories with Japanese articles on Muslim and Islam, as well as books and academic journals. I have come to the conclusion that Japanese society is becoming friendlier and showing understanding toward Islam culture and belief.
\end{abstract}

Keywords: Muslim community in Japan, Japanese society, disseminate knowledge about Islam

\section{INTRODUCTION}

This study takes the theme of the Muslim community in Japan, linked to the image of Islam in the Japanese society.

Due to geographical and historical reasons, the Islamic religion until the early 20th century is still less well known by Japanese society in general. Few of the Japanese people had the opportunity to interact with the Muslim community, therefore their knowledge and understanding of Islam and Muslims tend to be minimal. The majority of people know Muslims and Islam from the mass media. Unfortunately, the news about Islam and Muslims presented were mostly negative, because they were influenced by the Western media's perception. Especially after the events of $9 / 11$ in 2001, the Muslim image to the Japanese society tends to be 'frightening' (Komura, 2015).

To find out how the Japanese society responded to the presence of Muslims in its midst, I conducted in-depth interviews with 6 Muslims who lived in Japan. The results from the interviews then further verified against the news in the print media (electronic version). The purpose was to see if the negative tone in the mass media has discouraged the Japanese from further interaction with the Muslims, or on contrary had formed a new perception of Islam in Japan which formed from the interaction of society with the Muslim community around them. Thus, the new perception facilitates the Muslim community integration into Japanese society. 


\subsection{Muslim Life and Media Imagery}

In the period 1986-1991, Japan experienced an economic bubble, a situation where a very good economic condition entails increase in manpower demand. On the other hand, the labor force of the young generation (born after the 1960s) is accustomed to living comfortably causing them to be reluctant to perform heavy work with relatively low wages called $3 \mathrm{~K}$ jobs: kitanai (dirty), kitsui (heavy), kiken (dangerous). As a result, many companies are forced to bring-in foreign workers from countries with lower levels of prosperity than Japan, and among the foreign workers who came to Japan, there were also Muslims. After so many years of work, many of them decided to stay and became Japanese citizens, and lived among Japanese locals with minimal knowledge of Islam and worse, a negative image of Islam.

The foreign workers' community of each country is usually centered on a particular region, and each community tends to do business tailored to their respective skills and culture, such as restaurants, beauty salons, and travel agencies. Generally, Muslim workers in Japan worked in halal food stores and restaurants, or become nurses for the elderly. There were also those who work as company employees, factory workers, or lecturers. The rest are students, unskilled workers (those who work with trainee status).

As the number of community members increased, a place of worship is erected. Immigrants as members of a community made the effort to make frequent visits to places of worship. Their sense of unfamiliarity being in a foreign country with different cultures and social, economic, political circumstances tends to cause psychological pressure. Not infrequently they experience culture shock and must find a way to handle, stay afloat in and adapt to a new culture, i.e. through the practice of religion.

In fact, long before a major influx of Muslims who came to Japan in the 1990s, the Muslim community in Japan was formed when hundreds of Turkish refugees fled to Japan to escape the impact of the Russian Revolution during World War I. The Japanese government granted asylum and place them in several cities, including Kobe. The refugees then settled and erected a mosque in Kobe in 1914 (Azra, 2004). The mosque was renovated in 1935. The mosque is known as the Kobe Muslim Mosque. This was the foundation of Muslim community in Japan. The numbers of mosques in Japan today is quite numerous and facilitate Muslims to worship. The mosque do not only serve as a place of worship, but a place to socialize and exchange information, hold weddings and funerals, and to establish an identity as Muslim with fellow adherents.

Japanese Muslim constraints are not just foods, language, and work related. They also have to face the negative image of the media. A survey done among high school students in Japan in 2006 showed that $75 \%$ among the students believe Islam as an aggressive religion and $92 \%$ recognize Islam from the television media (Vestre, 2011).

The tragedy of the execution of 2 Japanese citizens by ISIS in 2015 became another factor triggering a negative image of Muslims. A number of representatives of Japanese mosques asked the media not to use the term Isuramu-koku (literally 'Islamic state') to refer to ISIS, as it would invite misunderstanding against Muslims in Japan. (Obe \& Hayashi, 2015). This incident could make Japanese citizens keep their distance from Muslims (information from an Indonesian woman Muslim student who happens to be veiled and studying in a private university in Tokyo). 


\section{ANALYSIS}

\subsection{The Japanese View of Islam and the Efforts from the Japanese Government to Change Their View into More Positive Way}

The article titled as ‘ムスリムと結婚して改宗した日本人女性たち’ (Musurimutachi to Kekkonshite Kaishūshita Nihonjin Joseitachi, Japanese Women Who Are Married to Muslim Men and Converted), posted on the website of 'Nippon.com' and it was released on September 6th 2017 and discussed Japanese women converts after marrying immigrant Muslims.

The first chapter discusses the experience of a female convert named Yuri with her husband, Ali. Yuri Gertz is a convert to Islam, having married Muhammad Ali Gertz, a Turkish Muslim. They are now living in Tokyo. Ali opened a kebab restaurant near Nakano station (one of the residential areas in central Tokyo) since 2016. Yuri works as an architect at a Japanese construction company. Yuri met Ali about 3 years earlier at a restaurant they frequented. In the restaurant, they often had conversations regarding foods and then later, they started dating. At first Yuri did not realize that Ali was a Muslim, because Ali never said openly. Yuri just learned that Ali was a Muslim when asked directly because he saw Ali did not eat some food. The following sentence containing one of Yuri's experiences on the image of Islam before she embraced Islam:

豚肉を食べない宗教、という程度のイメージしかなかった愉理さんだが

、海外からのイメージのよくないニュースは目にしていた。

(Butaniku wo tabenai shūkyō, to iu teido no imēji shikanakatta Yuri daga, kaigai kara no imēji no yokunai nyūsu wa me ni shite ita.)

(Translation: Though Yuri only has an image of Islam as a religion whose adherents do not eat pork, Yuri sees news from abroad which gave bad images of Islam, Media Text 3: 4.)

For Yuri at that time, Islam was a religion whose adherents do not eat pork. Yuri only knew the negative image of Islam from foreign news. Admittedly these images affected Yuri's perception of Islam. As a result of her discussions with Ali, Yuri gained a different understanding of Islam. Islam is often being portrayed as terrorism, a religion with backward culture, illegal immigrants, and many others. Vestre (2011: 104) reveals that in a 2010 event, suspicion of Muslims increased when the issue of investigation of Muslims on suspicion of terrorism, leaked and spread to the public. The suspicion that the Muslim population of Japan has the potential to become a source of terrorism, in fact has no solid basis. The displayed imagery actually created in the US. The mass media and popular culture took part in shaping the negative image of Muslims.

This view about Islam on Yuri is part changed when one day, Ali saw Yuri about to kill a mosquito. Ali tells Yuri to dismiss the mosquito instead of killing it. Ali even once caught a fly and releases it outside. Yuri did not conceal her surprise that there was a man as gentle as Ali. At that moment Yuri found how different was the reality and the news from the mass media about Muslims.

When she decided to marry Ali and become a convert, Yuri posed a question that has bothered her for awhile:

結婚を意識し始めたころ、自分も豚肉を食べない方がいいのかとアリさ

んに尋ねた。答えは意外だった。 
(Kekkon wo ishiki hajimeta koro, jibun mo butaniku wo tabenai houga ii noka to Ari-san ni tazuneta wa igaidatta.)

(When she started considering marriage, Yuri asked Ali whether Yuri herself should not eat pork.) Ali's answer was unexpected, Media Text 3: 6.)

Yuri asked whether she herself should not eat pork. Ali's answer was a total surprise to Yuri:

「それは愉理が決めるべきだ。あなたの、今までの大切なライフがあるで しょ」

(Sore wa Yuri ga kimerubeki. Anata no, imamade no taisetsu na raibu ga aru deshō.)

(Translation: You must decide it for yourself. You have a lifestyle of your own which you deem important up until now, right?, Text Media 3: 7.)

Ali argues that he has no say to Yuri's lifestyle. Even when he was the prospective husband, he told Yuri to prioritize her lifestyle first. According to him, Yuri should not let other people's opinions prevent her from building a spiritual relationship with God. Touched by Ali's words, Yuri was determined to convert and study Islam on her own:

強制されなかったからこそアリさんの信仰への敬意が生まれ、イスラム教 の勉強を始めた。

(Kyōsei sarenakatta kara koso Ali no shinkō he no keii ga umare, Isuramukyō no benkyō wo hajimeta.)

(Translation: Yuri's respect for the creed of Ali's then grew, Yuri started studying Islam, Media Text 3: 8.)

While she prepared herself for the conversion, Yuri stopped eating pork and drinking alcohol. All the kitchen wares which were contaminated with pork products were even replaced. Yuri's concerns were understandable considering Yuri was about to marry a Muslim. It is a common thing for Japanese to use ingredients such as pork and alcohol into their daily meal, such as ramen, cake, and crackers. Even in recent years halal meat is more frequently available, at that time the sale of which is still very limited and is still scarce. The halal certified meats (consumed by Muslims as the preparations adhere to Muslim sharia) are only available at a higher price compared to the meats sold in the market in general. The relatively higher price was due to the fact that Japan has to import halal meat from Australia, while halal chicken meat is imported from Brazil (Komura, 2015: 99).

The same concern was also found in the video 'Muslim Travelers-Umat Muslim di Nenba19 Juni 2015' which was uploaded in June 30th 2015. The video was recorded in Nenba village, Prefecture Yamanashi (west of Tokyo). Some Indonesians students reside there while studying, which include a student named Annisa. In this village, no mosque was found and halal food was virtually non existent, forcing Annisa to cook for herself. Annisa was informed by her senior that in Nenba, there is one store which sells halal food ingredients, including halal chicken meat imported from Brazil. In Japan, the stores which sell halal food exist only in some cities and towns, such as Mito-mito in the town of Kofu. In this store, Muslims can buy chicken, beef, and lamb with halal certificate. Other than from Brazil, certified halal meats are being imported from Australia and Thailand. It is said that this store has been in business since 20 years ago, yet has just recently started to sell halal meat in the last few years. 
After marrying Ali Gertz and became a convert, Yuri has not yet put on the hijab: 一方で愉理さんは、ヒジャブはモスクに行くとき以外は着用しないし、 礼拝も無理はしない。

(Ippō de Yuri wa, hijabu wa mosuku ni iku toki igai wa chakuyō shinaishi, reihai mo muri wa shinai.)

(Translation: On the other hand, Yuri does not cover her head by wearing hijab, except to go to a mosque and she had not forced herself to perform the shalat, Media Text 3: 11.)

Even though she has become a mualaf and started to learn Islam on her own, Yuri did not wear hijab, except when she was visiting the mosque; neither did she forced herself to perform the shalat. As for the hijab issue, Yuri was concerned about the reaction of her fellow coworkers and people closest to her. In fact, Yuri has been pondering about wearing hijab as her coworkers have a very vague understanding of Islamic belief. Yuri was hesitant lest people around her will feel uncomfortable. Nevertheless, in the end Yuri felt that the most important thing was how to worship Allah SWT, a practice of which would be dictated by Yuri herself.

Yuri's concern about wearing a hijab in the midst of the Japanese society was also apparent in the experience of a Japanese convert, named Junko Hayashi. The news reported in a article by the media 'The Mainichi' with a title 'Japanese Muslims face challenges at the workplace' published in January 4th 2016. Hayashi faces many challenges when seeking employment because her insistence on wearing a hijab. Hayashi had sent 40 work applications to the companies which focused on the field of energy and shipping and have business relation with Muslim countries. Only a handful companies invited Hayashi for an interview. In the end, no company hired her. Hayashi decided to become a lawyer and passed her exams in 2015.

Also cited in the same text, another Japanese woman whose name was not mentioned who became a convert in 2009. Concerned that she will be harassed by the people she has contact with, she wears hijab only on weekend. When she goes to work, she will replace the hijab with a knitted hat. In January 2015, the news of the killing of 2 Japanese by ISIS made the headlines. There was one time when the mentioned convert was in a train where she met an old lady. She was feeling scared because the old lady gave her a derogatory remark.

In the end of the text, Yuri expressed her hope that the knowledge that her husband Ali had try to teach to her, in turn will help her husband and other Muslims. In the long run, the knowledge and the ensuing mutual understanding will improve the life of Ali and other Muslims who live in Japan.

From the 'Foodnavigator-asia.com' in an article titled 'Tokyo offers incentives to halal food operators before the Olympics', more than 394.000 Muslim tourists came to Japan from Malaysia, according to Japan National Tourism Organization. From Indonesia itself, the tourists grew from previously 63.000 tourists to 271.000 tourists. These growths occurred in merely several years, between the years of 2009-2016. In another article posted in media 'This Week in Asia.com', titled as 'Why Are So Many Muslims Suddenly Visiting Japan?', it has been explained that the sudden growth of Southeast Asian tourists is caused by the act of the Japanese government relaxing visa requirements. This event also supported by the growing middle class with larger disposable income in Muslim countries, notably in South East Asia, and the growth in low-cost airlines serving Japan.

Should Japan open itself to the international world, it is even more urgent to revise this view of Islam into more positive ones. This way, the Japanese will have easier time to accept the Muslims, both those who come from the community and the tourists. Moreover, with the 
ongoing preparation of 2020 Olympic Games, many parties including the Japanese government, taking part in socializing Islam and by extension the Muslims, onto the Japanese society.

For an example, Muslim World League has made an agreement with Japan to become a provider that supply halal meals in 2020 Olympic Games. The said agreement was posted in the article titled as 'Muslim World League to Supply Halal Meals for Japan and 2020 Olympic Games' was posted in media 'Arab News'. This article was published in March 18th 2018. This agreement was signed by Mitsuhiro Miyakoshi (special adviser to Japanese Prime Minister), Prince Hiroyoshi (the cousin of the Emperor), and Mohammed bin Abdul Karim Al-Issa (the secretary general of Muslim World League). The Muslim World League, shortened as MWL, will become special provider halal certified meals in Japan in general and in the 2020 Olympic Games. The MWL was granted the right to regulate and in cooperation with the Japanese government, halal foods, and provide the best services. The MWL will also certify the products and services in accordance with the halal and hygienic standards. Furthermore, this organization will issue halal certification for products designated to Muslim communities in Japan.

In Japan itself, they have Japan Halal Foundation, shortened as JHF, an agency specialized in halal certification. The JHF base was located in Taito Ward, Tokyo. Currently, the JHF is in the process of being accredited by the Malaysian halal authority named as Jakim. This accreditation is important because when the companies wish to export to the Muslim countries, it would be better to have the products already certified and having the said accreditation. This way, the products will have more value.

In Toyota, Aichi Prefecture, a project to make a mobile mosque for 2020 Summer Olympic and Paralympic Games was on the way. This news was available in an article 'Company Unveils Mobile Mosque to Welcome Muslims Visiting Japan' from media of 'The Japan Times'. The games' organizers have spoken that the Muslim prayer rooms will only be available at the athletes' village. Tetsuro Akimoto, the head from the mentioned project, Yasuhara Inoue voiced his hope to provide a place where both Muslim athletes and spectators can pray. Furthermore, Yasuhara expressed that the possibility of not getting enough mosques for Muslim visitors for 2020 Olympic Games is alarming for Japan, a country which considered itself as a part of international community. Aside from the mobility, another of its advantages is that it can travel to any different Olympic venues and has its own washing area. The mobile prayer room was also equipped with air conditioner and can accommodate up to 50 people.

\subsection{Muslims Daily Life in Japan}

\subsubsection{Halal Food}

Access to halal food is an important factor for the Muslim community in Japan. The main obstacle to finding halal food in Japan is because of the limitations of shops and restaurants which prepare and sell halal food. Along with the growing population of foreign Muslim tourists and the population of the community, the Japanese government and Japanese began to open shops and restaurants that sell halal food.

In the early days of the settlement in Japan, DJ (respondent, hereinafter referred to as R1) was always anxious about finding halal food. Surprisingly, halal food could easily be found in Kobe. There were also a number of halal shops and restaurants. Previously some Indonesian 
halal restaurants can be found. However, these restaurants have been closed and only Indian restaurants remain in place and the number increases within a few years. Although the numbers are still very few in Kobe, some grocery stores even started selling halal food. Technological developments encourage the opportunity to sell halal food online. People originated from Indonesia for example, are increasingly doing their selling using halal online shop.

$\mathrm{N}$ (respondent, hereinafter referred to as R2), a Japanese mualaf and husband of R1, confessed that he did not encounter any food issues. But if he goes out to eat with colleagues, he will be more careful, because many foods in the restaurant are not halal.

In the early days of her arrival in Japan, A (respondent, hereinafter referred to as R3) had difficulty getting halal food. The same thing happened to her when looking for places of worship. R3 feels her life in Japan becomes easier because of increased access to halal food and an increase of places of worship. For example, with the presence of more and more mosques in malls and stations, the fact which made R3 feels that Japan is now friendlier towards Muslims.

$\mathrm{R}$ (respondent, hereinafter referred to as R4) confessed that it was not difficult for her to find halal food. In Kyoto, there are many shops that sell both halal ingredients as well as halal food. In addition, the relationship between Indonesian housewives and students from PPI (Indonesian Student Association) is very close. They share the same conditions that they came from Indonesia and they are usually able to cook as well. Likewise with her compatriots, R4 can cook on her own so as to save expenses.

DD (hereinafter referred to as R5), had constraints on getting halal food when she was only a few months ago into her stay in Kodaira (the area on the edge of Tokyo). Currently there are many shops selling halal foods, so halal foods are more easily found. R5 has a status as a student exchange for a period of 1 year at the University. Therefore tight schedules barely allow her to cook herself. When it comes to eating out, it is hard to find a halal restaurant located near her dorm since the number is still very small. R5 more often choose seafood instead of halal food. There are times when she felt bored with her meals because she could only consumed seafood.

\subsubsection{Worship}

Living a life as a Muslim in Japan is still challenging. Even though on the one hand, places of worship and shops and halal restaurants are increasingly easy to find. On the other hand, fasting in Japan is still creating a bit of a problem. The biggest difficulty when fasting in Japan is the long duration of fasting time. The month of Ramadan in these latest years usually falls in summer, where day duration is very long. Hereunder is a summary of statements of respondents.

According to R1, there are no obstacles during fasting in Japan. The only difficulty for her is the length of fasting. When fasting for the first time in Japan, the month of Ramadan at that time coincidences with the peak of summer. The heat had several times caused R 1 to break the fast. Her body weakened due to dehydration. After residing for quite a time in Japan, she began to get used to fasting. The shorter the time of fasting from year to year also facilitate her observance of fasting. It's just that Isya time in Japan is quite late and dawn is faster. Therefore R1 finds it difficult to prepare food for sahur. She cooks around $1.00 \mathrm{am}$, while dawn in Japan starts from 03.00 am.

The parents of R2 (husband of R1) adapt as much as possible to the condition of the R1 family. When they want to eat out, they look for food that can be eaten by the family. As is the 
case with snacks. They are even willing to prepare seafood meal when R1 and her family come to visit. During Ramadan, R1 and her family cease to visit their parents (R2 parents), not wanting to burden them with the trouble of preparing food. When R1 and R2 visit their parents will certainly provide many meals, whereas R1 and her family can not eat because of their fast. To communicate during Ramadan, when R1 and R2 refrain from visiting, they will instead call their parents.

Similar to Yuri's view before she was becoming a convert, the Islam image memorized by $\mathrm{R} 2$ is the result of mass media influence. Before becoming a convert and embraced Islam, R2 as a Japanese has an image of Islam as the other Japanese generally do. Allah SWT, Prophet Muhammad SAW, Arabs, and dressed all in white are some of the known Islamic images of $\mathrm{R} 2$. The Islam that was embedded in his mind was women dressed in black with only the eyes are visible, the countries which producing large quantities of oil, and act of terrorism. The first contact with the Muslim was when R2 made a visit to the Kobe Mosque and experienced a prayer service. At that time, R2 still did not know the Muslims. After the experience in the Kobe mosque, R2 embraced Islam the next day.

After becoming a convert, R2 became a member of a group studying Japanese language in a social media. In the study group, R2 met his future wife. During a visit to Indonesia, the image of Islam that was imprinted when has not yet embraced Islam then collapsed. During his visit in Indonesia, the relationship between R1 and R2 continued until they were married. When R2 told his parents and friends that he had become a convert, their faces turn strange, clearly they were very disturbed and concerned. However, as reported by R1, they basically respond with a normal attitude. They even congratulate R2 for his marriage. As a convert, R2 was invited to participate in studying Islam by a study group to which his wife (R1) also belonged. He admitted to having difficulties in learning Arabic and that to learn Arabic letters look like earthworms. Despite the difficulties, R2 also admitted it was the first time he has ever been accustomed to reading Arabic letters. He was also noted that in the mosque where R2 and his wife often visit, there was also a study group devoted to children.

Meanwhile in Kobe, only in recent years, according to R3, Japan has become easier to live in. For example, various halal foods stores and prayer rooms can be found with ease. Another noticeable change was the attitude toward hijab. When R3 had just settled in Japan, the use of hijab was looked upon as strange in the eyes of the Japanese. In the present, many Japanese have understood the reason for wearing the hijab and immediately recognize the wearer as Muslim. Difficulty in fasting was experienced by R3 when Ramadan comes. These last few years, the month of Ramadan in Japan coincides with the height of the summer season starting from July to August. As a caregiver in a nursing home, R3 is required to work professionally and R3 admitted how tiring it is without food intake and drink.

R3 was unable to perform tarawih prayers (prayer done in the night after one break his/her fast) in a congregation. R3 was also unable to join celebration with her friends, due to time constraints and distance to reach the mosque. However, even though she was unable to carry out tarawih, R3 with friends were able to join celebration every Eid Al-Fitr. When in a gathering with fellow Muslims, R3 feels like having met her family, especially during the gatherings with her fellow Indonesian Muslims. She also finds happiness because she feels closer to Allah SWT and more motivated to learn about Islam.

R4's confirmation is similar to that of the other respondents. In line with the increasing number of foreign Muslim tourists visiting Japan, more and more Japanese people have the awareness to provide a place of worship for them. For entrepreneurs, the preparation of a place of worship brings huge profits. In addition to the prayer rooms provided in the malls, restaurants, information centers, and stations, in Kokoka (Kyoto International Community 
House) the construction of a prayer room is being carried out. Kokoka is a place where Kyoto residents mingle, hang out, and discuss with foreigners. In planning the renovation, they have to make big changes because the place of worship to be built would have to fill a requirement of distinctive feature. They have also made sure that the prayer room for Muslims is clean and quiet. Based on R4 observations, the attitude of Japanese society is more friendly and open to immigrants, including Muslims. In addition to bringing in foreign exchange, the arrival of Muslim tourists gives a positive impact to the business and adds diversity to a vibrant local cultural heritage.

With regard to the obstacles experienced when fasting during Ramadan, R5 still have not the slightest idea. This year of 2018 is her first time of fasting observance in Japan. However, she felt it would be difficult, because her work starts from $17.00 \mathrm{pm}$. In Japan, the breaking of fasts starts around 18.30 to $19.00 \mathrm{pm}$.

\subsubsection{Work}

$\mathrm{R} 1$ is a housewife and works part-time as a volunteer in a nursing home. She works parttime to have free time to look after her 3-year-old daughter. Professional certification is not required because the status is only part-time worker. R2 works in the rehabilitation section of a clinic. R3 works as a caregiver in a nursing home. R5 is a student with a part-time job at a sushi restaurant. Of the six respondents, only R4 who does not hold a job, as currently she is studying as a doctoral student in her final level.

A part-time job for R1 is obtained from one of her Japanese acquaintances. While having a conversation, she was offered to work part time in a nursing home near her home. R1 came to the interview at the nursing home and was accepted for work. She became the only foreign worker in the nursing home. Working part-time means that workers are given freer working hours. This freedom allows R1 to take care of her daughter. R1 can take time off to seek another hoikusho (child daycare) until the child is accepted there. Since part-time workers do not need a license, many nursing homes now employ foreign workers. In addition to R1 and $\mathrm{R} 3$, more than 10 Indonesians work in the same nursing home.

$\mathrm{R} 2$ works in the clinic and is in charge of rehabilitation as a judo conservator. His job is to treat patients with muscle and bone injuries using judo movements. Initially because he worked in the field of health, he was interested in the structure of the human body. In development, he aspired to pursue knowledge and education in medical care.

Similar with R1 and R2, R3 also works in the health field. R3 works as a gerongik (a special elderly nurse), with the task of supporting the activities and cares for elderly patients suffering from various illnesses, including physical and mental illness. R3 chooses to be a nurse because she has basic knowledge as a nurse and is interested to continue her career as a nurse in the future. This interest encouraged her to further her education in the field of elderly nursing. R3 explained that wearing the hijab was not allowed by the nursing home managers. Until recently, wearing the hijab was allowed. Her husband, an Indonesian Muslim, also works in the same nursing home. Her husband works in the nutritional section as an assistant for the elderly.

Of all the respondents, only R5 has truly faced the obstacle of wearing a hijab. Previously, R5 was repeatedly rejected in various employments for wearing the hijab. The reason was because customers will be surprised and feel uncomfortable when visiting her prospective employers. Difficulties were also encountered by R5 when it was necessary to explain Islam to people who do not know anything about Muslims. Currently R5 makes a living by working 
part time at a sushi restaurant, where she works in the kitchen as a cook, while attending college from morning until the afternoon.

\subsection{Japanese Society and Muslim Community}

Regarding the image of Islam, R1 fells that the Japanese people in the housing complex are at least very normal on the surface. This phenomenon is likely due to the high Muslim population living in the city of Kobe. The same attitude was also felt when R 1 is in the workplace. If news on terrorism appears on media news, they never mention it. The father-inlaw did not give much commentary, except to comment on how horrific terrorism is. R1 hopes there is no terrorism in Japan.

Since R2 had become a convert, he also felt that nothing weird has happened in his surroundings. He did not experience any inconvenience. Although when it comes to food, since the number of halal restaurants is still small, he must be careful when going out to eat with colleagues.

According to R3, the question of whether the Japanese really want to know Islam is, all up to each one of them. Colleagues for example, often ask why R3 should wear the hijab and other things about Islam. R3 was also asked about martyrdom related matters. At that time the news about ISIS was heavily broadcasted. R3 gives explanations as much as possible so the Japanese natives do not misunderstand. Fortunately, after hearing her explanation, they ended up understanding the misconceptions.

Lecturers of R4 are Japanese people who have often interacted with Muslim students. They have been accustomed to the Muslim creed and customs and accepted if the lab party (party held in the laboratory) are serving halal or seafood menu. Even in the laboratory, Friday prayers are also commonplace. Some laboratory activities are adjusted to Friday prayer schedule. According to R4, as long as Japanese society sees Muslims as not being rude and disturbing, they will seek to accommodate the needs of the Muslim community.

Based on R4 observations, a new paradigm emerged among Japanese Muslims. This was revealed by one of her convert friends called Yuji Mizuno. The paradigm is that if the DKM (Mosque Prosperity Council) of the mosque has good contact with the police, then the position of the Muslim community will be safe. Especially, at times when the police have been readied around the mosque. The placement of the police gave them the perception that the DKM mosque has opened itself to the police, which mean the police became a supporter of various Muslim activities in the mosque. Yet it is another case if the mosque was ignored by the police. That means there is a problem between the Muslim community and the surrounding communities, represented by the police. This statement is supported by a statement from R4. In the early days of the ISIS news, police guards were often seen. Currently, the placement of the police is only seen during Eid Al-Fitr, Eid Al-Adha, and Friday prayers that coincide with the long holiday. Sometimes the police, accompanied by journalists, are covering mosque activities.

F (respondent, hereinafter referred to as R6) is a female Muslim who resides in Kyoto. She works as Indonesia's Ambassador for Kyoto and a member of Committee Council Multicultural Facility Kyoto City. Her duty as an Ambassador is to introduce Indonesia culture to schools and fureai (a face to face contact, usually intended for education and welfare). Sometimes she is requested by the school to explain about Islam. They are taking interest and having changed their perception, now that they know Islam is unlike the image that the mass media showed. There are times when they requested her to practice on how to wear hijab, how to do adzan and do shalat, and many more. 
According to R6, big cities such as Tokyo, Osaka, Kyoto, and Sapporo have been able to provide Muslim friendly facilities. Other than the increase of the Muslim friendly facilities, map in forms of leaflet and mobile applications for smartphone, have been released. Muslim friendly map for example, is a leaflet shaped city map created by the local government tourism agency. It shows various tourist spots which provide halal restaurant and praying space. R6 added further that the map is now also available in Tourist Information Centre and in halal restaurants.

\section{CONCLUSION}

Based on the elaboration of the results of text analysis and interviews, it can be concluded that there are many Japanese who act more friendly and accepting with the Muslim community. By finding more information through direct interaction, their understanding of the Muslim will grow deeper. This understanding will move them to socialize with the Muslims and improved the image of Islam. This change supported by the Japanese government's efforts to disseminate informations about Islam to the Japanese society, especially in conjunction with 2020 Olympic Games.

Government and private parties seek to increase the facilities of halal shops, halal restaurants, mosques, and prayer rooms. All of these developments are for the sake of familiarizing Islam within the society, as well as the convenience of the Muslim community. These efforts also helped spread a more positive Islam image and erase the negative ones. Another example is the establishment of cooperation between the police and the DKM (Mosque Prosperity Council) mosque in maintaining the safety of worship in the mosque, the development of mobile mosque for athletes in 2020 Summer Olympic Games, lab party using halal food and seafood, the increasing numbers of Muslims friendly cities, the availability of Muslim friendly map, and so forth.

\section{ACKNOWLEDGEMENT}

This research based on grant scheme of PITTA (Publikasi International Terindeks untuk Tugas Akhir) or also known as Indexed International Publications for Final Projects toward Universitas Indonesia students. Thank you to The Directorate of Research and Community Engagement of Universitas Indonesia (DRPM UI) for financial support

\section{REFERENCES}

[1]. Abdurakhman, Hasanudin. 2013. Minoritas Muslim di Jepang. Jakarta: Pena Nusantara.

[2]. Ahmadi, Abu, dkk. 2009. Ilmu Sosial Dasar. Jakarta: Rimeka Cipta.

[3]. AlSayyad, Nezar, Manuel Castells. 2002. Muslim Europe or Euro-Islam: Politics, Culture, and Citizenship in the Age of Globalization. US: Lexington Books.

[4]. Azra, Dr. Azyumardi. 2004. Japan, Islam, The Muslim World and Indonesia: Past and Present. Jakarta: The Japan Foundation Lecture Series.

[5]. Chung, Erin Aeran. 2010. Immigration and Citizenship In Japan. UK: Cambridge University Press.

[6]. Esposito, John L. 2015. World Religions Today. Jakarta: PT Elex Media Komputindo. 
[7]. Henslowe, Philip. 1999. Public Relations: A Practical Guide to the Basics. London: Clays Ltd.

[8]. Jefkins, Frank. 2004. Public Relations. Jakarta: Erlangga.

[9]. Joppke, Christian. 2009. Veil: Mirror of Identity. UK: Polity Press.

[10]. Kato, Hisanori. 2014. Islam di Mata Orang Jepang. Jakarta: PT Kompas Media Nusantara.

[11]. Komai, Hiroshi. 2001. Foreign Migrants in Contemporary Japan. Melbourne: Trans Pacific Press.

[12]. Komura, Akiko. 2015. 日本とイスラーム出会うとき : その歴史と可能性. Japan: Gendaishokan Ltd.

[13]. Kurasawa, Aiko. 2016. Masyarakat \& Perang Asia Timur Raya: Sejarah dengan Foto yang Tak Terceritakan. Jawa Barat: Komunitas Bambu.

[14]. Lavenda, Robert H., Emily A. Schultz. 2013. Core Concepts in Cultural Anthropology. New York: McGraw-Hill Companies.

[15]. Ogawa, Tadashi. 2007. テロと救済の原理主義. Japan: Shincho Sensho.

[16]. Ruben, Brent D., Lea P. Stewart. 2017. Komunikasi dan Perilaku Manusia. Jakarta: PT Rajagrafindo Persada.

[17]. Stokes, Jane. 2006. How To Do Media and Cultural Studies: Panduan untuk Melaksanakan Penelitian dalam Kajian Media dan Budaya. Terj. dari How To Do Media and Cultural Studies (Astuti, Santi Indra, Penerjemah). Yogyakarta: PT. Bentang Pustaka.

[18]. Sugimoto, Yoshio. 2003. An Introduction to Japanese Society: Second Edition. UK: Cambridge University Press.

[19]. Sulistyo-Basuki. 2006. Metode Penelitian. Wedatama Widya Sastra.

[20]. Suwarjeni, V. Wiratna.. 2014. Metodologi Penelitian. Yogyakarta: PT. Pustaka Baru.

[21]. Titscher, Stefan, Meyer, Michael, Wodak, Ruth, Eva Vetter. 2007. Methods of Text and Discourse Analysis. London: Sage Publications Ltd.

[22]. Ward, Colleen, Bochner, Stephen, Adrian Furnham. 2005. The Psychology of Culture Shock. USA: Taylor \& Francis e- Library.

[23]. Al-Sulami, Mohammed. 2018. "Muslim World League to supply halal meals for Japan and 2020 Olympic Games". Accessed August 18, 2018. http://www.arabnews.com/node/1268396/saudi-arabia.

[24]. Chung, Erin Aeran, Daisy Kim. 2012. "Citizenship and Marriage in a Globalizing World: Multicultural Families and Monocultural Nationality Laws in Korea and Japan.” Indiana Journal of Global Legal Studies, Vol. 19, No. 1 (Winter 2012), pp. 195-219. Accessed April 2, 2017. http://remotelib.ui.ac.id:2059/stable/pdf/10.2979/indjglolegstu.19.1.195.pdf.

[25]. Fathil, Fauziah, Fathiah Fathil. 2011. "Islam in Minority Muslim Countries: A Case Study in Japan and Korea." World Journal of Islam History and Civilization, 1 (2). Accessed March 19, 2017. http://www.idosi.org/wjihc/wjihc1(2)11/6.pdf.

[26]. Hideyuki, Kunihoda. 2017.“（5）ムスリムと結婚して改宗した日本人女性たち”. Accessed April 23 2018. https://www.nippon.com/ja/features/c04005/.

[27]. Ito, Masami. 2012. "Cremation Finds Favor even with Royal Clan.”. Accessed May 17, 2016.. https://www.japantimes.co.jp/news/2012/06/26/reference/cremation-finds-favoreven-with-royal-clan/\#.WwzMRDSFPMw

[28]. Kojima, Hiroshi. 2012. "Correlates of Cross-Border Marriages among Muslim Migrants in Tokyo Metropolitan Area: A Comparison with Seoul Metropolitan Area." Waseda Studies in Social Sciences, vol.13, No. 1. Accessed September 16, 2017. 
https://dspace.wul.waseda.ac.jp/dspace/bitstream/2065/38757/1/ShakaiKagakuSogoKe nkyu_13_1_Kojima.pdf.

[29]. Nakhleh, Emile A, Sakurai, Keiko, Michael Penn. 2008. "Islam in Japan: A Cause for Concern?.” Asia Policy, Number 5 (Januari 2008), 61-104. Accessed March 19, 2017. http://www.nbr.org/publications/asia_policy/Preview/AP5_IslamJapan_preview.pdf.

[30]. Nouh, Samir A. 2012. "Muslims in Japan with the Comparison of Those in Europe." Accessed March 19, 2017. http://web.cla.kobe-u.ac.jp/group/IReC/pdf/2012_nouh.pdf.

[31]. Obe, Mitsuru, Yuka Hayashi. 2015. "World News: Japan's Muslims Denounce Islamic State, Fear Backlash.” Wall Street Journal, Accessed December 4, 2017. https://remote-

lib.ui.ac.id:6066/docview/1650772582/4ED685EBF22542AEPQ/1?accountid=17242.

[32]. Okai, Hirofumi, Kiju Ishikawa. 2012. "Determinants of Local Residents' Perceptions and Attitude toward Islam and Muslims --A Case Study in Gifu City, Japan--."

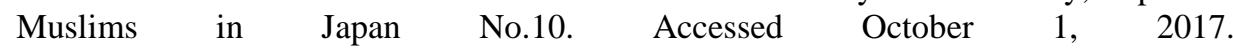
http://imemgs.com/document/gifusurvey_eng.pdf.

[33]. Osumi, Magdalena. 2016. "Schools Take In Tokyo Mosque to Get Unbiased Glimpse of Islam." Accessed December 4, 2017. https://remotelib.ui.ac.id:6066/docview/1793588517/5C5716AA2EAF4C2APQ/1?accountid=17242.

[34]. Ryall, Julian. 2017. "Why Are So Many Muslims Suddenly Visiting Japan?”. Accessed August 18, 2018. https://www.scmp.com/week-asia/society/article/2092664/why-areso-many-muslims-suddenly-visiting-japan.

[35]. Sputnik News. 2016. "Islamophobia? Japan's Top Court Approves Surveillance of Muslims." Accessed May 24, 2018. https://sputniknews.com/asia/201606291042190982-japan-mass-surveillanceMuslims/.

[36]. Tanada, Hirofumi, Ishikawa, Kiju, Hirofumi Okai. 2014. “Attitude Survey on Foreign Nationals Imizu City Report.” Muslims in Japan no. 13. Accessed October 1, 2017. http://imemgs.com/document/2014irumi.pdf.

[37]. Tanada, Hirofumi, Oka Hiroshi. 2015. “日本のイスラームーー ムスリム・コミュ ニティの現状と課題.”宗 務 時 報 no. 119. Accessed October 6, 2017. http://www.bunka.go.jp/tokei_hakusho_shuppan/shuppanbutsu/shumujiho/pdf/119jiho. pdf.

[38]. The Japan Times. 2018. "Company Unveils Mobile Mosque to Welcome Muslims Visiting Japan”. https://www.japantimes.co.jp/news/2018/07/29/national/companyunveils-mobile-mosque-welcome-muslims-visiting-japan/\#.W4EUDiQzbMw.

[39]. The Mainichi. 2016. "Japanese Muslims face challenges at the workplace". Accessed April 10, 2018. https://mainichi.jp/english/articles/20160104/p2a/00m/0na/014000c.

[40]. Vestre, Eskil O. 2011. "Japan as an Emerging Multicultural Society: Exploring Contemporary Minority Issues through the Case of Muslim Immigrants." Acceseed March 23 , 2017.

https://www.duo.uio.no/bitstream/handle/10852/24398/Vestre.pdf?sequence=2.

[41]. Whitehead, Richard. 2018. "Tokyo offers incentives to halal food operators before the Olympics". Accessed 18 August 2018. https://www.foodnavigatorasia.com/Article/2018/03/21/Tokyo-offers-incentives-to-halal-food-operators-beforethe-Olympics\#.

[42]. NET. Documentary. 2015. Muslim Travelers - Umat Muslim di Nenba, Jepang - 19 Juni 2015, June $30 . \quad$ Accessed, June 2018. https://www.youtube.com/watch?v=XzMbOOAfIeI. 